\title{
Jojoba (Simmondsia chinesis (Link) Schneider): A Potential Shrub in the Arabian Desert: II. Effect of Drought Stress on Vegetative Growth and Nutritive Value*
}

\author{
Hussein E. Osman and Atalla A. Abohassan \\ Department of Arid Land Agriculture, Faculty of Meteorology, \\ Environment \& Arid Land Agriculture, \\ King Abdulaziz University, Jeddah, Saudi Arabia
}

\begin{abstract}
The effect of seven irrigation regimes $(1,2,4,8,12,24$ and 48 week intervals) were assessed in a randomized complete block design field experiment in Western Saudi Arabia. Results of eight seasons (2 years) revealed no significant differences among the irrigations regimes on each of nine morphological traits studied, with the exception of plant height (summer) and specific leaf area (summer and winter), in the first year. In the second year, all traits, except for total dry weight and leaf weight in the autumn and number of leaves, in all seasons, were adversely affected by drought stress. On the average, estimates recorded at the 1,2, 4 and 8 weeks intervals were highest while those recorded at the 48 weeks interval were the lowest; and those recorded at the 12 and 24 weeks were intermediate in magnitude. Thus, depending on the season and the character under study, there were no clear boundaries among the irrigation regimes.

Drought stress had also significantly affected accumulation of $\mathrm{P}, \mathrm{K}, \mathrm{Cu}, \mathrm{Fe}$ and $\mathrm{Mn}$ contents in leaves, whereas that of $\mathrm{N}$ and $\mathrm{Zn}$ were not affected. On the average, lowest levels of $\mathrm{N}, \mathrm{P}, \mathrm{K}, \mathrm{Cu}$, and $\mathrm{Fe}$, and highest of $\mathrm{Mn}$ were recorded in the driest regime. Soil moisture contents generally increased with soil depth and decreased with drought stress whereas total amount of water applied in a period of 33 months ranged from 1719 to $4581 \mathrm{~m}^{3} \mathrm{ha}^{-1}$.
\end{abstract}

\section{Introduction}

Jojoba (Simmondsia chinesis (Link) Schneider) is a new industrial crop that is attracting attention in many semi arid parts of the world as its seeds contain appreciable amounts

\footnotetext{
*This research is supported under the grant AT-13-23 for King Abdulaziz City for Science and Technology
} (KACST), Saudi Arabia. 
$(50 \%)$ of a liquid wax that is needed to fill the gap created by termination of sperm oil production. Its great resistance to drought allows this shrub to produce a crop with significantly less water than is necessary for traditional crops. According to Al-Ani et al. (1972), jojoba plants were observed to tolerate water stress ranging from -48 to -59 bars water potential under field conditions to -70 bars under greenhouse conditions. According to Yermanos (1982), 250-450mm of annual rainfall were adequate for survival of natural jojoba populations. In experimental farms, however, vegetative growth and its components (Nerd et al., 1982; Benzioni and Nerd, 1985; Nerd and Benzioni, 1985; Ehrler et al., 1987; Benzioni and Dunstone, 1988; Malende, 1988; Nelson et al., 1993; and Nelson, 1996), mineral content of leaves and culms (El Tomi et al., 1984) and flowering (Nerd and Benzioni, 1988) were reported to vary with the intensity of drought stress.

It is well known, shortage of irrigation water is one of the main factors that limits crop production in arid and semi arid environments. Consequently, utilization of drought tolerant shrubs in sand stabilization and landscaping and greenification projects, in establishing open natural range lands and national parks will save adequate amounts of fresh water that can be used for cultivation of traditional field crops. Therefore, the present work was undertaken to assess the effect of extended drought periods on vegetative growth and mineral content of jojoba prior to its utilization in national projects in Western Saudi Arabia.

\section{Materials and Methods}

A two years field trial was conducted to assess the vegetative performance and nutritive value of jojoba under extended periods of drought stress. The trial was conducted at the Experimental Farm of King Abdulaziz University located in Hada Al-Sham at about $120 \mathrm{~km}$ northeast of Jeddah. The soil at the experimental site is sandy clay $(72 \%$ sand, $18 \%$ clay and $10 \%$ silt) with $\mathrm{pH} 8.2$ and an ECe of $0.96 \mathrm{dSm}^{-1}$. Meteorological data at experimental site are shown in Table 1. A seed lot, harvested from mature jojoba shrubs previously planted in the region, was sown on 28/2/1993 in an area of 1.024ha $(16$ rows $\times 4 \mathrm{~m} \times 160 \mathrm{~m})$ under a drip irrigation system. Plants within each row were spaced $2 \mathrm{~m}$ apart. The plot was later divided into four blocks, each of which, apart from marginal rows, consisted of 14 experimental rows, two of which were randomly allocated for each one of the seven irrigation treatments, namely, 1, 2, 4, 8, 12, 24 and 48 weeks irrigation intervals.

On 21/12/1993, i.e. after 297 days from planting, a flow-meter was connected to each of the 28 experimental plots and all plots were then irrigated on the same day. A week later, only plots allocated for the one week interval were irrigated. Consequently irrigation continued as scheduled in Table 2 until 21/3/1994. Following this date, irrigation was relaxed and all experimental plots were then irrigated every four weeks to avoid physiological shocks of extended stress on jojoba plants under the 12, 24 and 48 weeks irrigation interval in hotter part of the year. Starting 21/9/1994, i.e. after 182 days from the last scheduled irrigation and for eight consecutive seasons, i.e. until 21/9/1996, irrigation was provided on the basis of the seven intervals shown in Table 2. Meanwhile ten plants were randomly tagged from each experimental plot and at the end of each 
season and were used for measuring plant height, number of basal branches, basal branch length, number and total area of leaves per branch. In addition, leaf, culm and total dry weights of each branch and specific leaf area or SLA (i.e. leaf area/leaf weight) were also determined. Mineral contents of leaves and N-content of culms in four consecutive samples (seasons) of the last year and soil moisture content at variable depths at the end of the last year were also determined. Accumulated amounts of irrigation water applied in the course of the trial (33 months) and number of irrigations applied during the last 24 months were also recorded.

TABle 1. Absolute seasonal maxima and minima of temperature and relative humidity (R.H.) at the experimental site during the period from 21/12/94 to 21/12/96.

\begin{tabular}{|l|c|c|c|c|}
\hline \multirow{2}{*}{ Season 1 } & \multicolumn{2}{|c|}{$1994 / 95$} & \multicolumn{2}{c|}{$1995 / 96$} \\
\cline { 2 - 5 } & $\begin{array}{c}\text { Temp. } \\
\left({ }^{\circ} \mathrm{C}\right)\end{array}$ & $\begin{array}{c}\text { R.H. } \\
(\%)\end{array}$ & $\begin{array}{c}\text { Temp. } \\
\left({ }^{\circ} \mathrm{C}\right)\end{array}$ & $\begin{array}{c}\text { R.H. } \\
(\%)\end{array}$ \\
\hline Winter (W) & $10-42$ & $17-100$ & $24-41$ & $42-97$ \\
\hline Spring (Sp) & $18-49$ & $19-95$ & $25-47$ & $40-98$ \\
\hline Summer (S) & $21-48$ & $22-95$ & $31-49$ & $43-100$ \\
\hline Fall (F) & $20-46$ & $21-95$ & $22-44$ & $60-100$ \\
\hline
\end{tabular}

TABLE 2. Irrigation frequencies and total amount of irrigation used during the experimental period.

\begin{tabular}{|c|c|c|c|c|}
\hline S. no. & $\begin{array}{c}\text { Irrigation } \\
\text { regime } \\
\text { code }\end{array}$ & $\begin{array}{c}\text { Irrigation } \\
\text { interval } \\
\text { (weeks) }\end{array}$ & $\begin{array}{c}\text { Number of } \\
\text { irrigations* }\end{array}$ & $\begin{array}{c}\text { Total amount of water } \\
\text { used } \\
\left(\mathrm{m}^{3} / \mathrm{ha}\right)^{* *}\end{array}$ \\
\hline 1 & $\mathrm{R}_{1}$ & 1 & 105 & 4581 \\
\hline 2 & $\mathrm{R}_{2}$ & 2 & 53 & 3506 \\
\hline 3 & $\mathrm{R}_{3}$ & 4 & 27 & 2416 \\
\hline 4 & $\mathrm{R}_{4}$ & 8 & 14 & 1950 \\
\hline 5 & $\mathrm{R}_{5}$ & 12 & 9 & 1719 \\
\hline 6 & $\mathrm{R}_{6}$ & 24 & 5 & 1878 \\
\hline 7 & $\mathrm{R}_{7}$ & 48 & 3 & \\
\hline
\end{tabular}

*In the period extending between 21/9/94 to 21/9/1996.

**In the period extending between $21 / 12 / 93$ to $21 / 9 / 1996$.

\section{Results and Discussion}

Amounts of water applied in the period of 33 months ranged from 1719 to $4581 \mathrm{~m}^{3}$ $\mathrm{ha}^{-1}$, whereas number of irrigations ranged from 3 to 105 in the last 24 months (Table 2).

Differences in the plant height among the irrigation treatments were recorded in six out of the eight seasons during which the work was conducted (Fig. 1A). Apart from the summer of 1996, plant heights attained at $R_{1}, R_{2}$ and $R_{3}$ were significantly higher than those attained at $R_{7}$. Vegetative growth was similarly reported to decrease with increase of drought stress (Nerd et al., 1982; Benzioni and Nerd, 1985). 

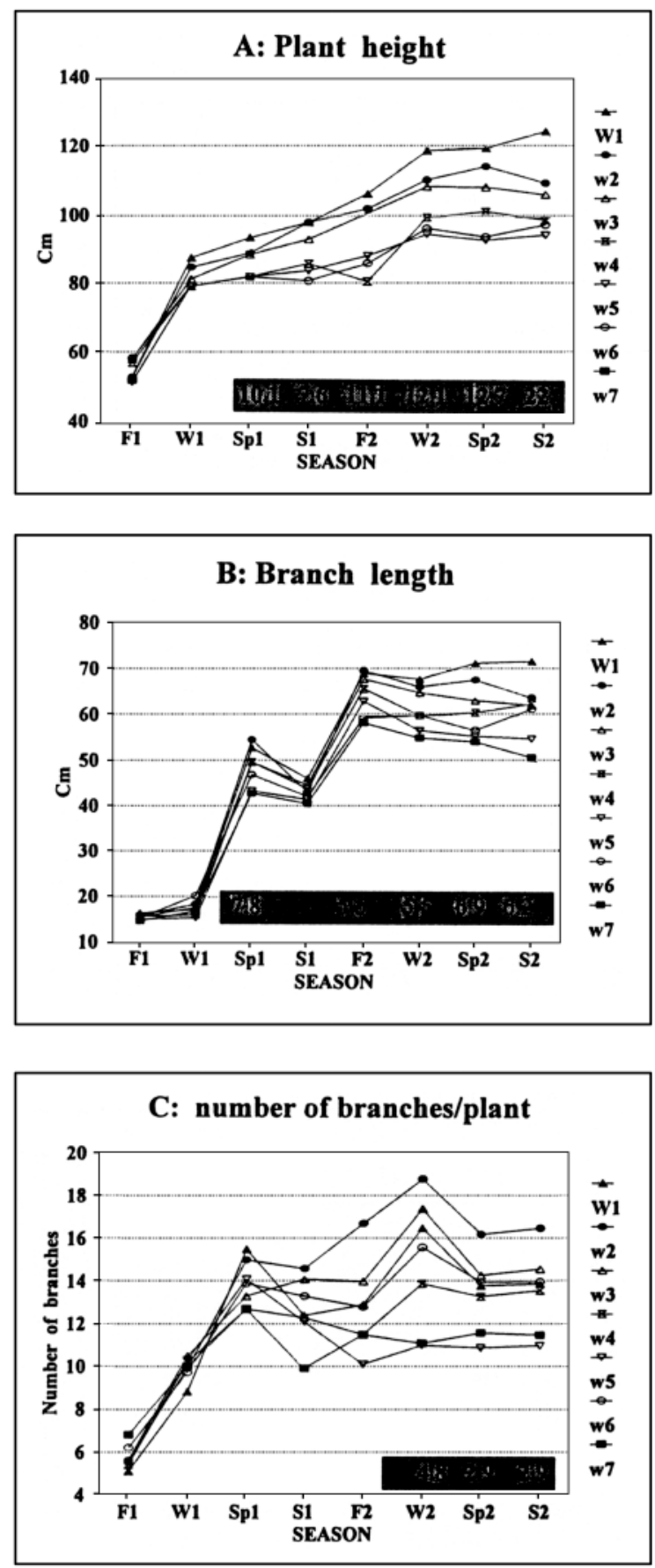

FIG. 1. Effect of drought stress on plant height (A), branch length (B) and number of branches per plant (C) in eight growing seasons (shaded figures refer to LSD at $\mathrm{P} \leq 0.05$ ). 



FIG. 2. Effect of drought stress on number of leaves per branch (A), total leaf area (B) and specific leaf area (C) in eight growing seasons (shaded figures refer to LSD at 0.05). 



FIG. 3. Effect of drought stress on leaf dry weight (A), culm dry weight (B) and total dry weight (C) in eight growing seasons (shaded figures refer to LSD at $\mathrm{P} \leq 0.05$ ). 
Effects of drought stress on branch length were similar to those on plant height. Differences among the irrigation regimes were recorded in five out of the eight seasons (Fig. 1B). Generally, treatments $R_{1}$ and $R_{2}$ at $S_{1}, R_{1}$ to $R_{3}$ at $W_{2}$ and $S_{2}, R_{1}$ to $R_{4}$ at $F_{2}$ and $R_{1}$ at the final date $\left(S_{2}\right)$ had significantly excelled $R_{7}$ (Fig. 1B).

Number of basal branches was relatively less affected by drought stress. Only number of branches attained at $R_{1}$ to $R_{3}\left(W_{2}\right)$ and at $R_{2}\left(S_{2}\right.$ and $\left.S_{2}\right)$ were significantly higher than those attained at $\mathrm{R}_{7}$ (Fig. 1C).

Number of leaves/branch in contrast to other traits, generally increased with drought stress. Differences among the seven irrigation regimes were, however, limited to the winter $\left(\mathrm{W}_{2}\right)$ of 1996. During this season number of leaves recorded at $\mathrm{R}_{6}$, being 504 , significantly excelled those recorded at $R_{1}$ (357) and $R_{2}$ (360), (Fig. 2A).

Total area of leaves per basal branch generally decreased with drought stress. However, significant differences among the irrigation regimes were limited to seasons $\mathrm{F}_{2}$, $\mathrm{Sp}_{2}$ and $\mathrm{S}_{2}$ of 1996 (Fig. 2B). Leaf areas attained at $\mathrm{R}_{4}$ at $\mathrm{F}_{2}$ and at $\mathrm{R}_{1}$ to $\mathrm{R}_{4}$ and $\mathrm{R}_{6}$ at $\mathrm{Sp}_{2}$ and $\mathrm{S}_{2}$ significantly excelled those attained at $\mathrm{R}_{7}$ (Fig. $2 \mathrm{~B}$ ).

Specific leaf area (SLA) or leaf area per unit leaf dry weight was highly affected by irrigation regimes. The magnitude of this effect and its direction varied, however, with the season and plant age (Fig. 2C). Apart from few exceptions, statistically highest estimates of SLA were recorded at $R_{1}, R_{2}$ and $R_{3}$, whereas lowest estimates were recorded at $R_{7}$. Among the exceptional cases, estimates recorded at $\mathrm{R}_{6}$ in seasons $\mathrm{W}_{1}, \mathrm{~S}_{1}, \mathrm{~W}_{2}$, and $\mathrm{Sp}_{2}$ and at $\mathrm{R}_{4}$ in $\mathrm{Sp}_{2}$ were statistically similar to those recorded at the wettest regime (Fig. 2C).

Effect of drought stress on leaf dry weight was limited to fall 1996 (Fig. 3A). At this stage, leaf dry weight recorded at $\mathrm{R}_{5}$, being $5.01 \mathrm{~g}$, was significantly higher than those recorded at $R_{1}(3.38 \mathrm{~g})$ and $\mathrm{R}_{2}(3.59 \mathrm{~g})$, indicating that leaf weight unlike number of leaves tended to increase with drought stress. Significant effects of drought on culm dry weight (CDW) were limited to the spring of 1996 (Fig. 3B). At this stage estimates recorded at $\mathrm{R}_{2}, \mathrm{R}_{4}$ and $\mathrm{R}_{1}$, being respectively $6.07,5.68$ and $5.31 \mathrm{~g}$ significantly outweighed those recorded at $R_{5}(4.19 \mathrm{~g})$ and $R_{7}(4.21 \mathrm{~g})$. Significant effects of drought stress on total dry weight (TDW) were recorded in the fall and the spring of 1996 (Fig. $3 \mathrm{C}$ ). In $\mathrm{F}_{2}$ dry weights attained at $\mathrm{R}_{4}$ and $\mathrm{R}_{5}$, being 9.6 and $9.8 \mathrm{~g}$ respectively, were higher than those recorded at $\mathrm{R}_{1}(7.3 \mathrm{~g})$ and $\mathrm{R}_{2}(7.4 \mathrm{~g})$, indicating that, at this stage, TDW similar to CDW and number of leaves tended to be higher at moderate stresses. At a later stage $\left(\mathrm{Sp}_{2}\right)$, however, TDW records at $\mathrm{R}_{7}$ and $\mathrm{R}_{5}$ were significantly lower than those at $\mathrm{R}_{2}$ and $\mathrm{R}_{4}$ (Fig. 3C).

Drought stress had significantly affected accumulation of $\mathrm{P}, \mathrm{K}, \mathrm{Cu}, \mathrm{Fe}$ and $\mathrm{Mn}$ contents of leaves; whereas that of $\mathrm{Zn}$ and of $\mathrm{N}$ (both leaves and culms) was not affected (Table 3). Although, lowest levels of N, P, K, Cu, and Fe, and highest levels of $\mathrm{Mn}$ accumulated at $\mathrm{R}_{7}$ (the driest regime), only accumulation of $\mathrm{Mn}$ appeared to be linearly related to drought stress, i.e. it increased with drought intensity (Table 3). Both $\mathrm{P}$ and $\mathrm{N}$ contents in jojoba roots were previously reported to decrease with drought stress (Malende, 1988), whereas those of $\mathrm{N}, \mathrm{P}, \mathrm{K}, \mathrm{Ca}, \mathrm{Mg}$ and $\mathrm{N}$ in the shoot were not affected (El Tomi et al., 1984). 
TABLE 3. Effect of irrigation regime and season on mineral content of jojoba leaves.

\begin{tabular}{|c|c|c|c|c|c|c|c|c|}
\hline \multirow{2}{*}{ Season } & \multicolumn{2}{|c|}{$\mathrm{N} \%$} & \multirow{2}{*}{$\begin{array}{l}\mathrm{P} \\
(\%)\end{array}$} & \multirow{2}{*}{$\begin{array}{l}\mathrm{K} \\
(\%)\end{array}$} & \multirow{2}{*}{$\begin{array}{c}\mathrm{Cu} \\
(\mathrm{Mg} / \mathrm{Kg})\end{array}$} & \multirow{2}{*}{$\begin{array}{c}\mathrm{Fe} \\
(\mathrm{Mg} / \mathrm{Kg})\end{array}$} & \multirow{2}{*}{$\begin{array}{c}\mathrm{Mn} \\
(\mathrm{Mg} / \mathrm{Kg})\end{array}$} & \multirow{2}{*}{$\begin{array}{c}\mathrm{Zn} \\
(\mathrm{Mg} / \mathrm{Kg})\end{array}$} \\
\hline & Leaf & Culm & & & & & & \\
\hline \multicolumn{9}{|c|}{ Irrigation regimes } \\
\hline (1) & 1.17 & 2.01 & 0.096 & 1.31 & 15.49 & 257.3 & 96.0 & 17.50 \\
\hline (2) & 1.29 & 2.10 & 0.102 & 1.39 & 14.55 & 231.0 & 109.3 & 19.50 \\
\hline (3) & 1.38 & 1.96 & 0.090 & 1.28 & 10.62 & 203.8 & 131.5 & 17.75 \\
\hline (4) & 1.24 & 2.08 & 0.099 & 1.47 & 15.17 & 254.8 & 151.8 & 29.75 \\
\hline (5) & 1.17 & 1.84 & 0.078 & 1.15 & 11.60 & 260.8 & 165.5 & 25.00 \\
\hline (6) & 1.18 & 18.4 & 0.087 & 0.93 & 8.77 & 273.0 & 175.0 & 15.00 \\
\hline (7) & 1.20 & 1.80 & 0.080 & 0.91 & 8.40 & 253.0 & 209.8 & 15.25 \\
\hline S.E. \pm & 1.23 & 1.95 & 0.090 & 1.21 & 12.08 & 204.5 & 148.4 & 19.96 \\
\hline Mean & 0.08 & 0.08 & $0.006^{*}$ & $0.13^{*}$ & $1.84 *$ & $15.6^{*}$ & $6.4^{* *}$ & 3.14 \\
\hline Fall 1995 & 1.26 & 2.11 & 0.087 & 1.39 & 12.52 & 217.0 & 132.4 & 18.71 \\
\hline Winter 1996 & 1.28 & 2.12 & 0.091 & 1.34 & 13.18 & 186.9 & 129.3 & 19.00 \\
\hline Spring 1996 & 1.10 & 1.73 & 0.097 & 1.15 & 11.23 & 281.3 & 161.0 & 19.43 \\
\hline Summer 1996 & 1.28 & 1.81 & 0.086 & 0.94 & 11.40 & 276.9 & 170.9 & 22.71 \\
\hline Mean & 1.23 & 1.95 & 0.090 & 1.21 & 12.08 & 240.5 & 148.4 & 19.96 \\
\hline S.E. \pm & 0.57 & $0.06^{* *}$ & 0.004 & $0.10^{*}$ & 1.38 & $11.8^{* *}$ & $4.8^{* *}$ & 2.58 \\
\hline
\end{tabular}

$*$ and $* *$ indicates significant differences at $\mathrm{P} \leq 0.05$ and $\mathrm{P} \leq 0.01$, respectively.

Soil moisture content significantly decreased $(\mathrm{P} \leq 0.01)$ with intensity of drought and increased with soil depth (Table 4). Adequate water was available at $\mathrm{R}_{1}$ to $\mathrm{R}_{4}$ in comparison to $R_{5}, R_{6}$ and $R_{7}$, indicating that significant differences observed between the two groups in most of the studied traits might, partially, be attributed to the differences in moisture content at different depths.

TABlE 4. Soil moisture content in jojoba field at variable depths under seven irrigation regimes recorded on 21/8/96.

\begin{tabular}{|l|c|c|c|c|c|c|}
\hline \multirow{2}{*}{$\begin{array}{c}\text { Irrigation } \\
\text { regime }\end{array}$} & \multicolumn{6}{|c|}{ Soil depth (cm) } \\
\cline { 2 - 7 } & $0-10$ & $10-20$ & $20-30$ & $30-40$ & $40-50$ & Mean \\
\hline & \multicolumn{7}{|c|}{ $\pm 0.75^{* *}$} & & \\
\hline$(1)$ & 3.54 & 4.19 & 8.01 & 8.12 & 8.00 & 6.37 \\
\hline$(2)$ & 4.24 & 4.19 & 3.98 & 5.51 & 5.34 & 4.65 \\
\hline$(3)$ & 2.22 & 3.82 & 3.72 & 3.69 & 3.37 & 3.36 \\
\hline$(4)$ & 1.81 & 3.14 & 3.87 & 3.69 & 2.68 & 3.04 \\
\hline
\end{tabular}


TABLE 4. (Cont'd).

\begin{tabular}{|l|c|c|c|c|c|c|}
\hline \multirow{2}{*}{$\begin{array}{c}\text { Irrigation } \\
\text { regime }\end{array}$} & \multicolumn{7}{|c|}{ Soil depth (cm) } \\
\cline { 2 - 7 } & $0-10$ & $10-20$ & $20-30$ & $30-40$ & $40-50$ & Mean \\
\hline$(5)$ & 1.20 & 1.54 & 1.60 & 1.74 & 2.30 & 1.68 \\
\hline$(6)$ & 0.92 & 1.30 & 1.44 & 3.49 & 3.51 & 2.13 \\
\hline$(7)$ & 0.98 & 1.56 & 1.88 & 2.15 & 2.32 & 1.78 \\
\hline S.E. \pm & \multicolumn{7}{|c|}{ $\pm 0.32^{* *}$} & 4.06 & 3.93 & \\
\hline Mean & 2.13 & 2.82 & 3.50 & & \\
\hline
\end{tabular}

**indicate significant differences among irrigation regimes and among soil depths at $\mathrm{P} \leq 0.01$.

It is thus evident from the present findings that jojoba in western Saudi Arabia, as in its original habitat had maintained positive growth under high drought stress. The ability to withstand drought could be attributed to its capability to cope with environmental changes through morphological modification such as reduction in leaf area and increase in leaf thickness or leaf weight (i.e. reduction in SLA) as observed in this study. The pale green color of the leaves and the stems as those of jojoba were reported to reflect light radiation and consequently reduce the amount of intercepted light. This in turn was observed to reduce evapotranspiration, lower leaf temperature and consequently improve water use efficiency (Gates, 1965; Doraiswamy and Rosenberg, 1974). The downward penetration of the root system and its proliferation within the soil layer were reported to be major determinants of the amount of water available and the rate at which it becomes accessible (Monteith, 1986) and consequently the amount of seed yield (Hurd, 1974), vegetative growth (Membani and Lal, 1983) or dry matter accumulation (Brown et al., 1987). Consequently, the deep and proliferated root system of jojoba (Yermanos, 1982) and its interaction with the shoot system to meet variations in water supply and atmospheric demand during the growing season (Monteith, 1986) had enabled it to withstand extreme drought stress. Reductions of osmotic potentials in the cells by about the same magnitude as that of the soil solution to avoid dehydration under high stress conditions (Maas and Nieman, 1977) by limiting some ions transfer from root to shoot (Bernstein and Howard, 1958) might have contributed to the ability of jojoba to withstand extended periods of drought stress.

\section{References}

Al-Ani, H.A., Strain, B.R. and Mooney, H.A. (1972) The physiological ecology of diverse populations of the desert shrub Simmondsia chinesis. J. Ecology 60: 41-57.

Benzioni, A. and Dunstone, R.L. (1988) Effect of air and soil temperature on water balance of jojoba growing under controlled conditions. Physiologia Plantarum 74: 107-112.

Benzioni, A., Mizrahi, Y. and Nerd, A. (1982) Effects of water and fertilization regimes on floral bud dormancy, fruit set and vegetative growth of jojoba plants. In: Proc 4th Inter. Conf. on Jojoba and its Uses, (I.M. Puebla (ed.), Hermosillo, Mexico, pp. 162-166, 196-170.

Benzioni, A. and Nerd, A. (1985) Effect of irrigation and fertilization on vegetative growth and yield of jojoba in relation to water status of the plant. Publication, Applied Res. Inst., Ben-Gurion Univ. of Negev, 44: $1-18$.

Bernstein, L. and Hayward, H.E. (1985) Physiology of salt tolerance, Ann. Rev. Plant Physiol. 9: 25-43. 
Brown, S.C., Keaeting, J.D.H., Gregory, P.J. and Cooper, P.J.M. (1987) Effect of fertilizer, variety and location on growth, Field Crops Res. 16: 53-66.

Doraiswamy, P.C. and Rosenberg, N.J. (1974) Reflectant induced modification of soybean canopy radiation balance. I. Preliminary tests with kalinite reflectant. Agron. J. 66: 224-228.

Ehrler, W.L., Frank, D.H. and Mitchell, S.T. (1987) Growth and yield of jojoba plants in stands using runoff-collecting micro catchments. Agron. J. 70: 1005-1009.

El-Tomi, A.L., Montassar, A.S., Behairy, Z.H., Bondok, A.Z. and El-Nahaas, M.A. (1984) Effect of irrigation on mineral content of jojoba plant. Ann. Agric. Sci., Ain Shams Univ., 29: 1055-1067.

Gates, D.M. (1965) Radiant energy: Its receipts and disposal. Meteor. Monographs 6: 1-26.

Hurd, E.A. (1974) Phenotype and drought tolerance in wheat. Agric. Meteorol. 14: 39-55.

Maas, E.V. and Nieman, R.H. (1977) Physiology of plant tolerance to salinity. U.S. Salinity Lab. Pub. \#600, Riverside, CA.

Malende, G.R. (1988) Nitrogen and mineral nutrition and water stress influence on vegetative growth of jojoba (Simmondsia chinesis (Link) Schneider). Agric. and Agron. Report (0285), DAI-B, 49/12:5071 (Univ. of Arizona, U.S.A.). 


\section{الهوهوبا : الشجيرة الواعدة في الصحر اء العربية}

\section{Y - أثر الإجهاد الرطوبي على النمو الخضري و القيمة الغذائية}

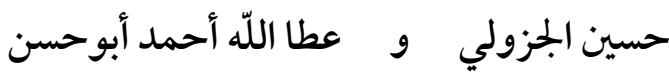

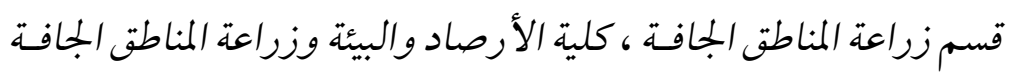



المستــخلص . نفــت التـجربة الحـاليـة بالمنطقة الغربيـة من المملكة

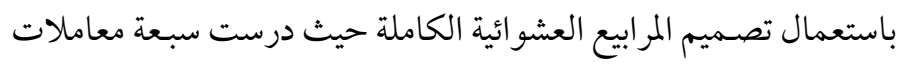



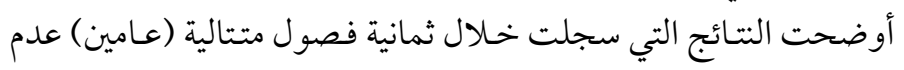

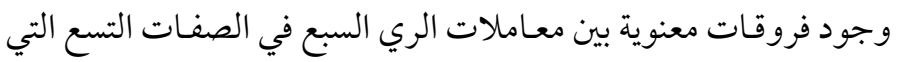

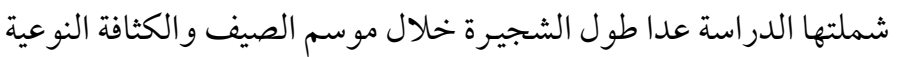



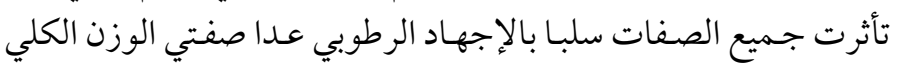



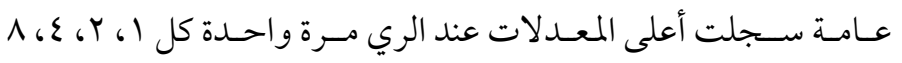



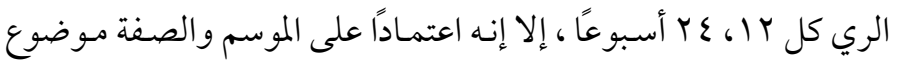



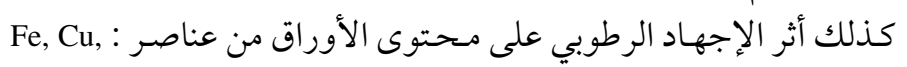

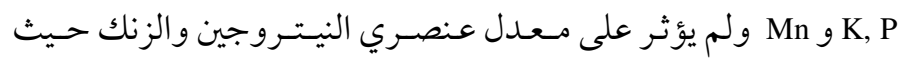

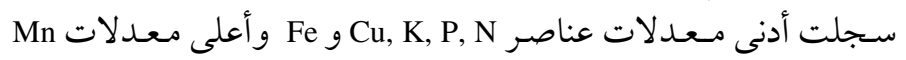

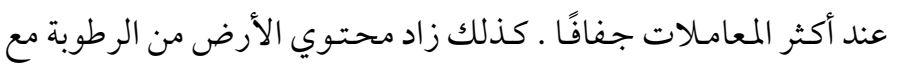



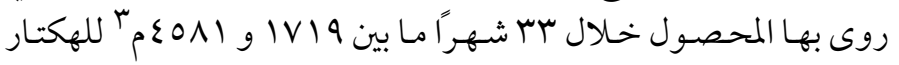



* أجرى هذا البحث بدعم من مدينة الملك عبد العزيز للعلوم والتقنية بالمنحة رقم أت-ب ا -ب؟r. 